\title{
EFFECTS OF SEMI-INTENSIVE CARP POND FARMING ON DISCHARGED WATER QUALITY
}

\author{
Lucie VŠETIČKOVÁ ${ }^{1 *}$, Zdeněk ADÁMEK ${ }^{2}$, Miloš ROZKOŠNÝ ${ }^{3}$, and Pavel SEDLÁČEK ${ }^{3}$ \\ ${ }^{1}$ Department of Botany and Zoology, Faculty of Science, Masaryk University, Brno, Czech Republic \\ ${ }^{2}$ University of South Bohemia in České Budějovice, Faculty of Fisheries and Protection of Waters, South Bohemian \\ Research Center of Aquaculture and Biodiversity of Hydrocenoses and Research Institute \\ of Fish Culture and Hydrobiology, Zátiši 728/II, 38925 Vodñany, Czech Republic \\ ${ }^{3}$ Water Research Institute of Tomáš Garrigue Masaryk, Mojmírovo náměstí 16, 61200 Brno, Czech Republic
}

Všetičková L., Adámek Z., Rozkošný M., Sedláček P. 2012. Effects of semi-intensive carp pond farming on discharged water quality. Acta Ichthyol. Piscat. 42 (3): 223-231.

\begin{abstract}
Background. Fish pond management can substantially modify the hydrological regime and ecological quality of receiving waters (usually rivers, canals, and ponds downstream in an interconnected system) with potentially positive or negative impacts on watershed functioning. To evaluate these effects with respect to carp pond management, the environmental impacts of semi-intensive farming on discharged water quality were monitored at four differently managed carp ponds, differing in trophic status (two eutrophic and two hypertrophic ponds).

Materials and methods. Fundamental determinants of pond inflow and outflow water quality were monitored monthly from April to October 2009. Water temperature, $\mathrm{pH}$, and dissolved oxygen concentration and saturation were measured in situ whilst hydrochemical and microbiological parameters were assessed in the laboratory.

Results. Compared to the inflow water, in the effluents there was a significant decline in numbers of bacterial loading indicators (Escherichia coli, enterococci, faecal coliform and mesophilic bacteria) in the outflow water. In ponds with the poor quality inflow water (downstream of water treatment plant discharges), a significant decrease was also registered in nutrients $\left(\mathrm{N}-\mathrm{NH}_{4}, \mathrm{~N}-\mathrm{NO}_{3}\right.$, total nitrogen, $\mathrm{P}-\mathrm{PO}_{4}$, and total phosphorus) and organic loads? (five-day biological oxygen demand, chemical oxygen demand) of pond effluents. At the pond supplied with good quality river water, however, the same determinants showed that effluent water quality worsened significantly. Total organic carbon and suspended solids increased in effluents of ponds with high fish biomass stocked.

Conclusion. The results demonstrate that, during the growing season, properly managed carp ponds represent ecosystems with high self-cleaning ability. They may play an important role in the nutrient balance, storage and trapping in agricultural landscape with high population density.
\end{abstract}

Keywords: carp farming, pond aquaculture, pond effluents, bacterial loading, nutrients, water quality

\section{INTRODUCTION}

The environmental effects of aquaculture range from highly detrimental to highly beneficial, depending on the perspective of the observer and the type of aquaculture activity (Bert 2007). The influence of intensive aquaculture (trout farming in particular) on discharged water quality has been the topic of many studies since the second half of the 20th century (Alabaster 1982, Einen et al. 1995, Bergheim and Åsgård 1996). Common carp production, however, as practiced in Central and Eastern Europe (i.e., in semi-intensive fish ponds), has not been studied nearly as much, despite many indications that it can have a significant positive or negative influence on the water quality of the receiving water body.

Pond farming is an aquacultural technology tightly linked with its surrounding environment, influencing it and being reciprocally influenced by it. The extensive and semi-intensive management systems typical for Czech pond aquaculture include complex production methods with numerous important links within the pond environment itself, to other connected ponds, and to the surrounding ecosystem. In consequence, watershed management upstream of fish ponds can significantly affect their functioning by either enhancing or reducing productivity. Further, fish pond management can substantially modify the hydrological regime and ecological quality of receiving waters (usually rivers, canals, and ponds downstream in an interconnected system), again with potentially positive or negative impacts on watershed functioning. Depending on the management measures used to improve and/or control productivity, therefore, fish ponds can either discharge

\footnotetext{
* Correspondence: Dr Lucie Všetičková, Ústav botaniky a zoologie, Přírodovědecká fakulta, Masarykova univerzita, Kotlářská 2,61137 Brno, Czech Republic, phone: +420731 189 287, e-mail: lucka.kocanda@seznam.cz.
} 
harmful waste water into downstream water systems, or act as water bodies in which beneficial ecological processes, including natural self-purification (biodegradation of organic matter, nutrient retention, etc.), can take place.

Up until the beginning of the 20th century, intensification measures were not used by carp fish pond farmers. During the 1930s, however, liming and manuring (addition of organic fertiliser) of ponds became commonplace (Pechar 2000) and, by the 70s and 80s, fertilisation (addition of organic and/or inorganic fertiliser) and the use of artificial feeds had become common means of intensification. At present, two principal means of "intensification" are applied in the Czech Republic (neither of which approach "intensive" fish farming technologies): "extensive" culture, in which fish production is based exclusively on natural food resources; and "semi-intensive" culture, based on natural diet supported by fertilisation and/or by supplemental feeding, mainly of cereals (approximately 25\%-30\%; Adamek et al. 2008). Although technologies applied in pond farming show great diversity, semi-intensive polyculture remains the dominant form of pond management practice in the Czech Republic and, more generally, in Central and Eastern Europe. The combination of increasing municipal, industrial and agricultural sources of pollution and eutrophication with such intensification measures, however, has resulted in extremely high nutrient input into pond ecosystems since the last decades of the 20th century (Fasaic et al. 1989, Muscutt et al. 1993). Despite pond manuring and fertilisation being severely restricted by law in Czech fish ponds at present, fish feeding (though limited) and stocking density are still frequently blamed by nature protection and water management agencies for significant deterioration in discharged water quality.

At ponds surrounded by arable land, agricultural runoff has frequently led to eutrophication in ponds (KnudHansen et al. 2003, Nhan et al. 2006); while fish pond management, e.g., excessive fish-stock biomass, may also have a direct influence on bacterial numbers, with bacterial populations enriched to such an extent that water quality is too poor for recreation (Markošová and Ježek 1994). The main chemical elements contaminating pond waters are phosphorus $(\mathrm{P})$ and nitrogen $(\mathrm{N})$. Under Central European conditions, the trapping and storage of $\mathrm{P}$ and $\mathrm{N}$ is considered an important function of fish ponds, as documented in numerous German, Austrian, Hungarian, Polish, and Czech studies (Gergel and Kratochvil 1984, Oláh et al. 1994, Kainz 1985, Knösche et al. 2000, Drabiński et al. 2010). Highest $P$ values have been usually found in sediment deposits that, according to Bíró (1995), can store 100-1000 times more nutrient than water.

Pond aquaculture has very deep historical roots in Central Europe. In recent years, however, fish ponds have also come to be considered as an integral part of the landscape (Ciesla et al. 2008), with ponds currently playing an important role in recreation, water management, and nature protection. In addition, many Czech fish ponds primarily designed for fish farming also serve as recipients of pollution, predominantly in the form of high nutrient loading from waste water treatment plants (Heteša et al. 2002). The multifunctional role of Czech ponds results in relatively low production figures compared to intensive pond aquaculture, the average yearly figure being slightly below $500 \mathrm{~kg}$ per ha (of which carp make up about $450 \mathrm{~kg}$ per ha; Adamek et al. 2008).

In this study, we evaluate and compare the water quality at pond inlet and outlet canals during the fish growing season from ponds subject to a range of pressures and management styles. The study sites selected include ponds supplied partly or fully with water discharged from waste-water treatment plants and from unpolluted river water. Thus, the aim of the study was to estimate the nutrient and bacterial loadings of water discharged continuously from carp ponds compared with the pond inflow loadings.

\section{MATERIAL AND METHODS}

Study sites. Monitoring was performed from April to October 2009 on four earthen ponds (often referred to as carp ponds in Central Europe) in South Moravia (Czech Republic) managed under different regimes:

1. Two on-growing ponds designated for two-year-old fish production:

- extensively farmed Kurdějovský pond (KUR; $48^{\circ} 56^{\prime} 1^{\prime \prime} \mathrm{N}, 16^{\circ} 46^{\prime} 40^{\prime \prime} \mathrm{E}$ ),

- semi-intensively farmed Šibeník pond (SIB; $48^{\circ} 47^{\prime} 0^{\prime \prime} \mathrm{N}, 16^{\circ} 37^{\prime} 49^{\prime \prime} \mathrm{E}$ ), and

2. Two marketing ponds designated for marketable (usually three-year-old) fish production:

- extensively farmed Nesyt pond (NES; $\left.48^{\circ} 45^{\prime} 59.65^{\prime \prime} \mathrm{N}, 16^{\circ} 44^{\prime} 8.561^{\prime \prime} \mathrm{E}\right)$ with two inlets:

- Valtický brook (VAL) and the

- Včelínek canal (VCE), and,

- the semi-intensively farmed Vrkoč pond (VRK; 48 $55^{\prime} 30^{\prime \prime} \mathrm{N}, 16^{\circ} 33^{\prime} 46^{\prime \prime} \mathrm{E}$ ).

All four ponds are located in depressions surrounded by arable land. Basic data on pond characteristics and fish stocking densities are presented in Tables 1 and 2, respectively. Nesyt pond is situated in a National Nature Reserve and fish farming management is practised according to a maintenance program set down by the Agency for Nature Conservation and Landscape Protection of the Czech Republic.

The ponds studied have been stocked with eight fish species: grass carp, Ctenopharyngodon idella (Valenciennes, 1844); bighead carp, Hypophthalmichthys nobilis (Richardson, 1845); silver carp, Нуроphthalmichthys molitrix (Valenciennes, 1844); tench, Tinca tinca (L.); wels catfish, Silurus glanis L.; northern pike, Esox lucius L.; and pike-perch, Sander lucioperca (L.) (Table 2).

Methods. Water quality parameters were monitored monthly at both inlet- and outlet canals and the data obtained were presented as inflow/effluent comparisons. Water temperature, $\mathrm{pH}$, and dissolved oxygen (DO) concentration and saturation were measured in situ using a $\mathrm{HACH}$ Lange HQ40d multimeter. Hydrochemical parameters 
Table 1

Basic characteristics of the ponds studied

\begin{tabular}{|c|c|c|c|c|c|c|c|}
\hline \multirow[b]{2}{*}{ Pond } & \multirow{2}{*}{$\begin{array}{c}\text { Area } \\
{[\text { ha }]}\end{array}$} & \multirow{2}{*}{$\begin{array}{l}\text { Trophic } \\
\text { status }\end{array}$} & \multicolumn{2}{|c|}{ Inflow $\left[\mathrm{L} \cdot \mathrm{s}^{-1}\right]$} & \multirow{2}{*}{$\begin{array}{l}\text { Outflow } \\
{\left[\mathrm{L} \cdot \mathrm{s}^{-1}\right]}\end{array}$} & \multirow{2}{*}{$\begin{array}{l}\text { Retention Time } \\
\text { [days }]\end{array}$} & \multirow{2}{*}{$\begin{array}{c}\text { Yearly fish } \\
\text { production } \\
{\left[\mathrm{kg} \cdot \mathrm{ha}^{-1}\right]}\end{array}$} \\
\hline & & & Value & Source & & & \\
\hline KUR & 6.58 & $E$ & $2.6 \pm 1.1$ & WTP & $0.7 \pm 0.3$ & 104 & 737 \\
\hline SIB & 28.65 & $\mathrm{E}-\mathrm{P}$ & $17.0 \pm 9.9$ & WTP & $16.2 \pm 10.0$ & 168 & 1071 \\
\hline NES & 289.66 & EU & $\begin{array}{c}76.2 \pm 44.2 \\
7.2 \pm 7.3\end{array}$ & $\begin{array}{l}\text { P (VCE) } \\
\text { WTP (VAL) }\end{array}$ & $67.8 \pm 118.8$ & 184 & 716 \\
\hline VRK & 156.08 & $\mathrm{E}-\mathrm{P}$ & $314.8 \pm 209.8$ & $\mathrm{R}$ & $25.8 \pm 39.5$ & 88 & 1112 \\
\hline
\end{tabular}

KUR $=$ Kurdějovský pond, SIB $=$ Šibeník pond, NES = Nesyt pond, VRK = Vrkoč pond; E = eutrophic, E-P = eutrophic to polytrophic (according to Adámek et al. 2010); WTP = water treatment plant, $\mathrm{P}=$ pond, VCE = Včelínek canal, VAL = Valtický brook, $\mathrm{R}=$ river.

Table 2

Fish stocking densities of the ponds studied

\begin{tabular}{|c|c|c|c|c|c|}
\hline \multirow{2}{*}{ Fish species } & \multirow{2}{*}{$\begin{array}{c}\text { Age } \\
\text { [years] }\end{array}$} & \multicolumn{4}{|c|}{ Stocking density $\left[\mathrm{kg} \cdot \mathrm{ha}^{-1}\right]$} \\
\hline & & KUR & SIB & NES & VRK \\
\hline \multirow{4}{*}{ Common carp, Cyprinus carpio } & 1 & 38 & & & \\
\hline & 2 & & 168 & 29 & 76 \\
\hline & 3 & & 405 & 201 & 379 \\
\hline & 4 & & & & 64 \\
\hline \multirow{3}{*}{ Grass carp, Ctenopharyngodon idella } & 1 & 30 & & & \\
\hline & 3 & & 84 & & 14 \\
\hline & 4 & & & & 1 \\
\hline Bighead carp, Hypophthalmichthys nobilis & 2 & & 33 & & \\
\hline Silver carp, Hypophthalmichthys molitrix & 2 & & & & 13 \\
\hline \multirow{2}{*}{ Tench, Tinca tinca } & 1 & 30 & & & \\
\hline & 4 & 6 & & 2 & \\
\hline \multirow{3}{*}{ Wels catfish, Silurus glanis } & 1 & 2 & & & \\
\hline & 2 & & 1 & & \\
\hline & 3 & & & + & 5 \\
\hline \multirow{2}{*}{ Northern pike, Esox lucius } & 1 & & 1 & 4 & 1 \\
\hline & 3 & & & & + \\
\hline \multirow{3}{*}{ Pike-perch, Sander lucioperca } & 1 & & + & & \\
\hline & 2 & & & + & 1 \\
\hline & 5 & & & 1 & \\
\hline TOTAL & & 106 & 692 & 237 & 554 \\
\hline
\end{tabular}

KUR $=$ Kurdějovský pond, SIB = Šibeník pond, NES = Nesyt pond, VRK = Vrkoč pond; $+=$ density $<0.5 \mathrm{~kg} \cdot \mathrm{ha}^{-1}$.

assessment covered suspended solids (SS), biochemical sites (In, Out) were pooled to compare the differences oxygen demand $\left(\mathrm{BOD}_{5}\right)$, chemical oxygen demand between the inflow ("In") and effluent ("Out") water qual$\left(\mathrm{COD}_{\mathrm{Mn}}\right)$, total organic carbon (TOC), $\mathrm{N}-\mathrm{NH}_{4}, \mathrm{~N}-\mathrm{NO}_{3}$, total ity parameters. In cases of heterogeneity of variances nitrogen (TN), $\mathrm{P}_{-} \mathrm{PO}_{4}$, total phosphorus (TP), chlorophyll- $a$, ( $F$-test) the $t$-test for separate variation estimates was used. and trophic potential. Microbiological evaluation included evaluation of enterococci, Escherichia coli, faecal coliform bacteria count $(\mathrm{FCB})$, and mesophilic $\left(22^{\circ} \mathrm{C}\right)$ organisms count (MO). Both hydrochemical and microbiological parameters were assessed at the TGM Water Research Institute laboratories in Brno certified according to ISO 9001: 2009, using accredited methods ${ }^{*}$. No data were available for September at the KUR outlet as there was no discharge due to an exceptionally hot and dry summer season.

Statistical analysis. The Student's $t$-test was applied in order to test for differences between water quality parameters from pond inlets and outlets. For this purpose, the data from individual sampling campaigns in individual

\section{RESULTS}

Kurdějovský pond (KUR). Compared to the inlet canal, at the outlet canal of this pond a highly significant decrease $(P<0.01)$ was observed in enterococci numbers (Table 3 ) and TN content (Table 4), with E. coli numbers and $\mathrm{MO}\left(22{ }^{\circ} \mathrm{C}\right)$ (Table 3$)$, and trophic potential, phosphates $\left(\mathrm{P}-\mathrm{PO}_{4}\right), \mathrm{TP}$, ammonium $\left(\mathrm{N}-\mathrm{NH}_{4}\right)$, and nitrates $\left(\mathrm{N}_{-} \mathrm{NO}_{3}\right)$ (Table 4) also showing a significant decline though at a slightly lower level $(P<0.05)$.

Šibeník pond (SIB). Compared to the inlet canal, at the outlet canal of this pond a highly significant decrease $(P<0.01)$ in $\mathrm{P}_{-} \mathrm{PO}_{4}, \mathrm{TP}, \mathrm{N}-\mathrm{NO}_{3}$ (Table 4$)$, and in trophic

\footnotetext{
${ }^{*}$ Certificate of Good Laboratory Practice No. 389 for the T.G. Masaryk Water Research Institute, p.r.i., Brno Branch Office testing laboratory, Issued by: ASLAB Středisko pro posuzování způsobilosti laboratoří, Prague 2010. Registration number 4051
} 
potential (Table 5) was recorded; while a significant $(P<0.01)$ increase was recorded in DO concentration, $\mathrm{pH}$, oxygen saturation (Table 6), and chlorophyll- $a$ content (Table 5). There was also a slightly less significant $(P<0.05)$ decrease in microbiological parameters, with a drop in enterococci numbers, $E$. coli numbers, faecal coliform bacteria (Table 3), and in TN (Table 4). At the same time, there was a significant $(P<0.05)$ increase in BOD $_{5}$ (Table 6) and TOC (Table 5).

Nesyt pond (NES). Inflow water quality differed considerably between the two inlet canals (VCE and VAL). Faecal coliform bacteria and $E$. coli numbers were significantly $(P<0.01)$ higher at VCE compared to outlet water quality (Table 3); and significant levels $(P<0.05)$ were also recorded in discharged $\mathrm{SS}$ (presented as dry matter at $105^{\circ} \mathrm{C}$ ) content (Table 4).

Compared to VAL, outlet water quality showed a significant increase in DO concentration, $\mathrm{pH}$ and oxygen saturation (Table 6), and in chlorophyll- $a$ concentration (Table 5). There was a significant $(P<0.01)$ decrease in TP concentration at the outlet compared to VAL, but not for VCE (Table 4). The outlet also had significantly $(P<0.05)$ lower levels of E. coli (Table 3), $\mathrm{P}_{-} \mathrm{PO}_{4}, \mathrm{TN}$ and $\mathrm{N}-\mathrm{NH}_{4}$ concentrations (Table 4), and a lower trophic potential (Table 5) compared to the VAL inlet.

The Vrkoč pond (VRK). The VRK outlet showed significant $(P<0.01)$ declines in $\mathrm{TN}$ and $\mathrm{N}-\mathrm{NO}_{3}$ concentrations (Table 4) and in trophic potential (Table 5). On the other hand, significant increases $(P<0.01)$ were observed in SS content (Table 4) and, at a lower level of significance $(P<0.05)$ in $\mathrm{BOD}_{5}, \mathrm{COD}_{\mathrm{Mn}}$ (Table 6) and chlorophyll- $a$ concentration (Table 5).

\section{DISCUSSION}

Water quality differed considerably between the inlet canals and between the two inlets (VCE and VAL) at the NES pond in particular. The VCE canal is an artificial waterway bringing water from upstream ponds, NES being the third pond downstream in a connected series of six large carp ponds. Treated water from a small village $(\sim 1300$ inhabitants) waste water treatment plant (WWTP) is discharged immediately upstream of the VCE sampling site.

VCE water quality, however, is considered adequate for the purposes of pond management as it does not carry any noticeable loading (Rozkošný et al. 2011). On the

Table 3

A comparison of microbiological parameters of the inlet- and outlet waters of the ponds studied

\begin{tabular}{llcccc}
\hline Pond & Sampling site & $\begin{array}{c}\text { Enterococci } \\
{\left[\mathrm{CFU} \cdot \mathrm{mL}^{-1}\right]}\end{array}$ & $\begin{array}{c}\text { Escherichia coli } \\
{\left[\mathrm{CFU} \cdot \mathrm{mL}^{-1}\right]}\end{array}$ & $\begin{array}{c}\mathrm{FCB} \\
{\left[\mathrm{CFU} \cdot \mathrm{mL}^{-1}\right]}\end{array}$ & $\begin{array}{c}\mathrm{MO} \\
{\left[10^{3} \mathrm{CFU}^{-1} \mathrm{~mL}^{-1}\right]}\end{array}$ \\
\hline \multirow{2}{*}{ KUR } & In & $30.9 \pm 18.2^{\mathrm{A}}$ & $19.1 \pm 17.7^{\mathrm{a}}$ & $33.0 \pm 38.0$ & $79.0 \pm 56.4^{\mathrm{a}}$ \\
& Out & $3.7 \pm 3.8^{\mathrm{B}}$ & $1.7 \pm 1.4^{\mathrm{b}}$ & $3.0 \pm 4.0$ & $22.9 \pm 14.6^{\mathrm{b}}$ \\
\multirow{2}{*}{ SIB } & In & $41.4 \pm 36.2^{\mathrm{a}}$ & $37.3 \pm 31.1^{\mathrm{a}}$ & $66.0 \pm 45.0^{\mathrm{a}}$ & $26.2 \pm 13.7$ \\
& Out & $1.5 \pm 1.1^{\mathrm{b}}$ & $1.0 \pm 0.8^{\mathrm{b}}$ & $3.0 \pm 2.0^{\mathrm{b}}$ & $16800 \pm 9229$ \\
\multirow{2}{*}{ NES } & In VCE & $8.5 \pm 8.1$ & $26.5 \pm 18.7^{\mathrm{a}}$ & $43.0 \pm 22.0^{\mathrm{A}}$ & $13.3 \pm 6.8$ \\
& In VAL & $1425 \pm 1641$ & $8699 \pm 9607^{\mathrm{b}}$ & $13345 \pm 15571$ & $5834 \pm 7668$ \\
\multirow{2}{*}{ VRK } & Out & $1.9 \pm 1.4$ & $2.5 \pm 2.8^{\mathrm{c}}$ & $6.0 \pm 6.0^{\mathrm{B}}$ & $8.8 \pm 3.5$ \\
& In & $10.0 \pm 14.9$ & $13.6 \pm 16.8$ & $27.0 \pm 38.0$ & $21.1 \pm 11.2$ \\
\hline
\end{tabular}

Data are mean \pm standard deviation; Data with superscripts differed significantly at $P<0.05$ (lowercase) or $P<0.01$ (uppercase); KUR = Kurdějovský pond, SIB = Šibeník pond, NES = Nesyt pond, VRK = Vrkoč pond, VCE = Včelínek canal, VAL $=$ Valtický brook; $\mathrm{CFU}=$ colony forming unit, $\mathrm{FCB}=$ faecal coliform bacteria, $\mathrm{MO}=$ mesophilic organisms number (at $\left.22^{\circ} \mathrm{C}\right) ; \mathrm{In}=$ inlet (inflow), Out $=$ outlet (effluent).

Table 4

A comparison of hydrochemical parameters and t-test between of the inlet- and outlet waters of the ponds studied

\begin{tabular}{|c|c|c|c|c|c|c|c|}
\hline Pond & $\begin{array}{l}\text { Sampling } \\
\text { site }\end{array}$ & $\begin{array}{c}\mathrm{P}-\mathrm{PO}_{4} \\
{\left[\mathrm{mg} \cdot \mathrm{L}^{-1}\right]}\end{array}$ & $\begin{array}{c}\mathrm{TP} \\
{\left[\mathrm{mg} \cdot \mathrm{L}^{-1}\right]}\end{array}$ & $\begin{array}{c}\mathrm{SS} \\
{\left[\mathrm{mg} \cdot \mathrm{L}^{-1}\right]}\end{array}$ & $\begin{array}{c}\mathrm{N}-\mathrm{NH}_{4} \\
{\left[\mathrm{mg} \cdot \mathrm{L}^{-1}\right]}\end{array}$ & $\begin{array}{c}\mathrm{N}-\mathrm{NO}_{3} \\
{\left[\mathrm{mg} \cdot \mathrm{L}^{-1}\right]}\end{array}$ & $\begin{array}{c}\mathrm{TN} \\
{\left[\mathrm{mg} \cdot \mathrm{L}^{-1}\right]}\end{array}$ \\
\hline \multirow{2}{*}{ KUR } & In & $0.62 \pm 0.28^{a}$ & $0.96 \pm 0.31^{\mathrm{a}}$ & $24.17 \pm 10.90$ & $5.91 \pm 3.75^{\mathrm{a}}$ & $1.46 \pm 0.94^{\mathrm{a}}$ & $8.82 \pm 2.69^{\mathrm{A}}$ \\
\hline & Out & $0.21 \pm 0.22^{b}$ & $0.49 \pm 0.33^{b}$ & $35.00 \pm 45.61$ & $1.00 \pm 0.84^{b}$ & $0.33 \pm 0.28^{b}$ & $2.82 \pm 1.26^{\mathrm{B}}$ \\
\hline \multirow{2}{*}{ SIB } & In & $2.69 \pm 0.84^{\mathrm{A}}$ & $3.35 \pm 0.92^{\mathrm{A}}$ & $24.33 \pm 10.29$ & $3.75 \pm 5.18$ & $4.20 \pm 2.38^{\mathrm{A}}$ & $10.75 \pm 6.40^{a}$ \\
\hline & Out & $0.92 \pm 0.47^{\mathrm{B}}$ & $1.26 \pm 0.39^{\mathrm{B}}$ & $28.33 \pm 9.25$ & $0.19 \pm 0.15$ & $0.53 \pm 0.73^{\text {в }}$ & $3.31 \pm 1.27^{\mathrm{b}}$ \\
\hline \multirow{3}{*}{ NES } & In VCE & $0.32 \pm 0.26^{\mathrm{a}}$ & $0.63 \pm 0.29^{\mathrm{A}}$ & $71.50 \pm 29.85^{\mathrm{A}}$ & $0.21 \pm 0.16^{\mathrm{A}}$ & $0.45 \pm 0.40$ & $2.71 \pm 0.93^{\mathrm{A}}$ \\
\hline & In VAL & $3.23 \pm 1.92^{b}$ & $4.72 \pm 2.69^{\mathrm{B}}$ & $48.50 \pm 36.49^{\mathrm{B}}$ & $9.81 \pm 10.20^{\mathrm{B}}$ & $1.73 \pm 1.77$ & $16.03 \pm 11.74^{\mathrm{B}}$ \\
\hline & Out & $0.38 \pm 0.16^{\mathrm{a}}$ & $0.60 \pm 0.13^{\mathrm{A}}$ & $35.33 \pm 7.87^{\mathrm{B}}$ & $0.24 \pm 0.12^{\mathrm{B}}$ & $0.17 \pm 0.11$ & $2.68 \pm 0.94^{\mathrm{A}}$ \\
\hline \multirow{2}{*}{ VRK } & In & $0.28 \pm 0.20$ & $0.48 \pm 0.21$ & $38.50 \pm 18.57^{\mathrm{A}}$ & $0.51 \pm 0.54$ & $2.12 \pm 1.21^{\mathrm{A}}$ & $4.75 \pm 0.50^{\mathrm{A}}$ \\
\hline & Out & $0.18 \pm 0.08$ & $0.46 \pm 0.12$ & $99.33 \pm 37.63^{\mathrm{B}}$ & $0.08 \pm 0.07$ & $0.29 \pm 0.39^{\mathrm{B}}$ & $3.03 \pm 0.88^{\mathrm{B}}$ \\
\hline
\end{tabular}

Data are mean \pm standard deviation; Data with superscripts differed significantly at $P<0.05$ (lowercase) or $P<0.01$ (uppercase); KUR $=$ Kurdějovský pond, SIB $=$ Šibeník pond, NES $=$ Nesyt pond, VRK = Vrkoč pond, In = inlet (inflow), Out $=$ outlet $($ effluent), $\mathrm{VCE}=$ Včelínek canal, $\mathrm{VAL}=$ Valtický brook; $\mathrm{TP}=$ total phosphorus, $\mathrm{SS}=$ suspended solids, $\mathrm{TN}=$ total nitrogen. 
Table 5

A comparison of TOC values, chlorophyll- $a$ content, and trophic potential of inlet- and outlet waters of the ponds studied

\begin{tabular}{|c|c|c|c|c|}
\hline Pond & Sampling site & $\begin{array}{c}\mathrm{TOC} \\
{\left[\mathrm{mg} \cdot \mathrm{L}^{-1}\right]}\end{array}$ & $\begin{array}{c}\text { Chlorophyll- } a \\
{\left[\mu \mathrm{g} \cdot \mathrm{L}^{-1}\right]}\end{array}$ & $\begin{array}{c}\text { Trophic potential } \\
{\left[\mathrm{mg} \cdot \mathrm{L}^{-1}\right]}\end{array}$ \\
\hline \multirow{2}{*}{ KUR } & In & $12.13 \pm 1.51$ & $7.80 \pm 11.38$ & $195.42 \pm 50.48^{\mathrm{a}}$ \\
\hline & Out & $14.42 \pm 5.35$ & $53.14 \pm 98.97$ & $111.52 \pm 37.50^{\mathrm{b}}$ \\
\hline \multirow{3}{*}{ SIB } & In & $12.32 \pm 4.69^{\mathrm{a}}$ & $10.93 \pm 4.10^{\mathrm{A}}$ & $395.08 \pm 118.62^{\mathrm{A}}$ \\
\hline & Out & $17.60 \pm 2.95^{b}$ & $139.57 \pm 58.99^{\mathrm{B}}$ & $141.36 \pm 84.08^{\text {В }}$ \\
\hline & In VCE & $14.70 \pm 2.90$ & $98.35 \pm 40.13^{\mathrm{a}}$ & $116.90 \pm 81.26^{\mathrm{A}}$ \\
\hline \multirow[t]{2}{*}{ NES } & In VAL & $30.22 \pm 24.94$ & $8.28 \pm 11.46^{\mathrm{b}}$ & $285.50 \pm 99.96^{\mathrm{B}}$ \\
\hline & Out & $16.80 \pm 3.73$ & $55.30 \pm 41.17^{b}$ & $133.72 \pm 101.32^{\mathrm{A}}$ \\
\hline \multirow{2}{*}{ VRK } & In & $14.93 \pm 4.09$ & $86.57 \pm 57.27^{\mathrm{a}}$ & $152.78 \pm 39.25^{\mathrm{A}}$ \\
\hline & Out & $20.13 \pm 5.18$ & $172.47 \pm 66.01^{b}$ & $69.52 \pm 38.26^{\mathrm{B}}$ \\
\hline
\end{tabular}

Data are mean \pm standard deviation; Data with superscripts differed significantly at $P<0.05$ (lowercase) or $P<0.01$ (uppercase); KUR = Kurdějovský pond, SIB = Šibeník pond, NES = Nesyt pond, VRK = Vrkoč pond, In = inlet (inflow), Out = outlet (effluent), VCE = Včelínek canal, VAL = Valtický brook; TOC = total organic carbon.

Table 6

A comparison of physico-chemical parameters of the inlet- and outlet waters of the ponds studied

\begin{tabular}{|c|c|c|c|c|c|c|c|}
\hline Pond & $\begin{array}{l}\text { Sampling } \\
\text { site }\end{array}$ & $\mathrm{pH}$ & $\begin{array}{c}\mathrm{DO} \\
{\left[\mathrm{mg} \cdot \mathrm{L}^{-1}\right]}\end{array}$ & $\begin{array}{c}\mathrm{O}_{2} \text { saturation } \\
{[\%]}\end{array}$ & $\begin{array}{c}\mathrm{BOD}_{5} \\
{\left[\mathrm{mg} \cdot \mathrm{L}^{-1}\right]}\end{array}$ & $\begin{array}{c}\mathrm{COD}_{\mathrm{Mn}} \\
{\left[\mathrm{mg} \cdot \mathrm{L}^{-1}\right]}\end{array}$ & $\begin{array}{c}\text { Water } \\
\text { temperature } \\
{\left[{ }^{\circ} \mathrm{C}\right]}\end{array}$ \\
\hline \multirow{2}{*}{ KUR } & In & $7.93 \pm 0.16$ & $6.02 \pm 1.04$ & $64.90 \pm 11.55$ & $3.90 \pm 1.22$ & $6.35 \pm 0.73$ & $17.6 \pm 1.6$ \\
\hline & Out & $7.94 \pm 0.19$ & $7.16 \pm 1.64$ & $78.08 \pm 17.15$ & $6.59 \pm 6.49$ & $8.71 \pm 3.09$ & $18.4 \pm 2.9$ \\
\hline \multirow{2}{*}{ SIB } & In & $7.67 \pm 0.09^{\mathrm{A}}$ & $4.01 \pm 0.63^{\mathrm{A}}$ & $43.52 \pm 6.25^{\mathrm{A}}$ & $3.54 \pm 3.00^{\mathrm{a}}$ & $6.84 \pm 0.83$ & $18.0 \pm 2.1$ \\
\hline & Out & $8.74 \pm 0.17^{\mathrm{B}}$ & $8.63 \pm 0.70^{\mathrm{B}}$ & $98.03 \pm 7.25^{\mathrm{B}}$ & $8.10 \pm 3.20^{b}$ & $8.06 \pm 1.17$ & $20.4 \pm 3.2$ \\
\hline \multirow{3}{*}{ NES } & In VCE & $8.10 \pm 0.20^{\mathrm{a}}$ & $7.72 \pm 1.17^{\mathrm{A}}$ & $84.57 \pm 9.36^{\mathrm{A}}$ & $7.67 \pm 1.81$ & $6.18 \pm 1.13$ & $18.8 \pm 2.5$ \\
\hline & In VAL & $7.78 \pm 0.16^{\mathrm{a}}$ & $2.75 \pm 1.80^{\mathrm{B}}$ & $29.02 \pm 19.49^{\mathrm{B}}$ & $28.14 \pm 33.43$ & $12.53 \pm 6.55$ & $15.5 \pm 2.1$ \\
\hline & Out & $8.12 \pm 0.27^{\mathrm{ab}}$ & $6.23 \pm 1.62^{\mathrm{A}}$ & $68.40 \pm 19.24^{\mathrm{A}}$ & $5.17 \pm 2.52$ & $7.67 \pm 2.10$ & $18.2 \pm 2.7$ \\
\hline \multirow{2}{*}{ VRK } & In & $8.07 \pm 0.47$ & $8.42 \pm 1.11$ & $91.72 \pm 8.75$ & $6.87 \pm 2.31^{\mathrm{a}}$ & $8.94 \pm 1.32^{\mathrm{a}}$ & $18.5 \pm 2.8$ \\
\hline & Out & $7.99 \pm 0.32$ & $6.87 \pm 2.09$ & $72.00 \pm 23.67$ & $11.12 \pm 3.30^{\mathrm{b}}$ & $10.72 \pm 1.54^{\mathrm{b}}$ & $19.4 \pm 3.0$ \\
\hline
\end{tabular}

Data are mean \pm standard deviation; Data with superscripts differed significantly at $P<0.05$ (lowercase) or $P<0.01$ (uppercase); KUR = Kurdějovský pond, SIB = Šibeník pond, NES = Nesyt pond, VRK = Vrkoč pond, In = inlet (inflow), Out $=$ outlet (effluent), $\mathrm{VCE}=$ Včelínek canal, $\mathrm{VAL}=$ Valtický brook; $\mathrm{DO}=$ dissolved oxygen, $\mathrm{BOD}_{5}=$ biochemical oxygen demand, $\mathrm{COD}_{\mathrm{Mn}}=$ chemical oxygen demand.

other hand, the VAL inlet suffered from severe loading by untreated waste water discharged from an upstream WWTP (serving 3600 inhabitants) that was undergoing complete reconstruction during the sampling campaign. This led to dramatically increased figures for inflow bacteria and nutrient loading, particularly during April-June and October 2009 (Figs. 1 and 2) when no treatment (except for sedimentation) was provided. The oxygen regime of the VAL inflow also altered dramatically during these periods (Fig. 3). As a result, average bacterial counts were linked with extremely high standard deviations, making proof of significant difference between inflow and outflow water impossible, despite differences in enterococci, E. coli and faecal coliform bacteria ranging between thousands of $\mathrm{CFU} \cdot \mathrm{mL}^{-1}$ and single digit figures, and MO levels ranging from millions to thousands $\mathrm{CFU} \cdot \mathrm{mL}^{-1}$ between inflow and outflow waters (Table 3 ).

Water quality based on saprobiological evaluation of macrozoobenthos improved significantly at the pond outlets (Všetičková and Adámek 2012). This was in good accordance with the values of microbiological parameters
(Table 3), which showed significant declines in the outlets of all ponds under study. Most evident was the decline in enterococci at the KUR outlet, which dropped from 32.0 to $0.75 \mathrm{CFU} \cdot \mathrm{mL}^{-1}$ in October, representing a 97.7-percentage-point reduction. A similarly high reduction was recorded for the July SIB samples, which dropped from 74 to $0.78 \mathrm{CFU} \cdot \mathrm{mL}^{-1}$, which is a 98.9 -percentage-point decrease. Counts of E. coli also declined at pond outlets, with the most noticeable contrast seen at the NES pond (VAL inlet to NES outlet) in May, when E. coli were reduced from $22000 \mathrm{CFU} \cdot \mathrm{mL}^{-1}$ to only $0.2 \mathrm{CFU} \cdot \mathrm{mL}^{-1}$ at the outlet. The decrease in MO level was most obvious at the KUR pond in October, with a 92.9-percentage-point reduction $\left(181000\right.$ to $\left.12850 \mathrm{CFU} \cdot \mathrm{mL}^{-1}\right)$.

Values of $\mathrm{pH}$ increased slightly at the outlets and this was clearly related to an increase in chlorophyll- $a$ content (Tables 5 and 6). The most significant change in $\mathrm{pH}$ was recorded at the SIB pond in June when $\mathrm{pH}$ increased from 7.57 to 9.0 , corresponding to a 15.9-percentage-point increase. Concurrently, the inflow DO concentration and chlorophyll- $a$ content increased from 3.5 to $12.8 \mathrm{mg} \cdot \mathrm{L}^{-1}$, 
and from 10.1 to $173 \mathrm{mg} \cdot \mathrm{L}^{-1}$, respectively in pond out- tem (Milstein et al. 1991) in summer. Trophic potential let. The only exception in $\mathrm{pH}$ dynamics was at VRK, was lowered at pond outlets, which denotes nutrient retenwhere $\mathrm{pH}$ was lower at the outlet, though the difference tion by the pond, a fact already indicated by the largely was negligible ( $<1$ percentage point) and was probably significant decreases in nutrient concentration in outflow associated with increased respiration of the pond ecosys- waters (see Table 4). The decrease in trophic potential was

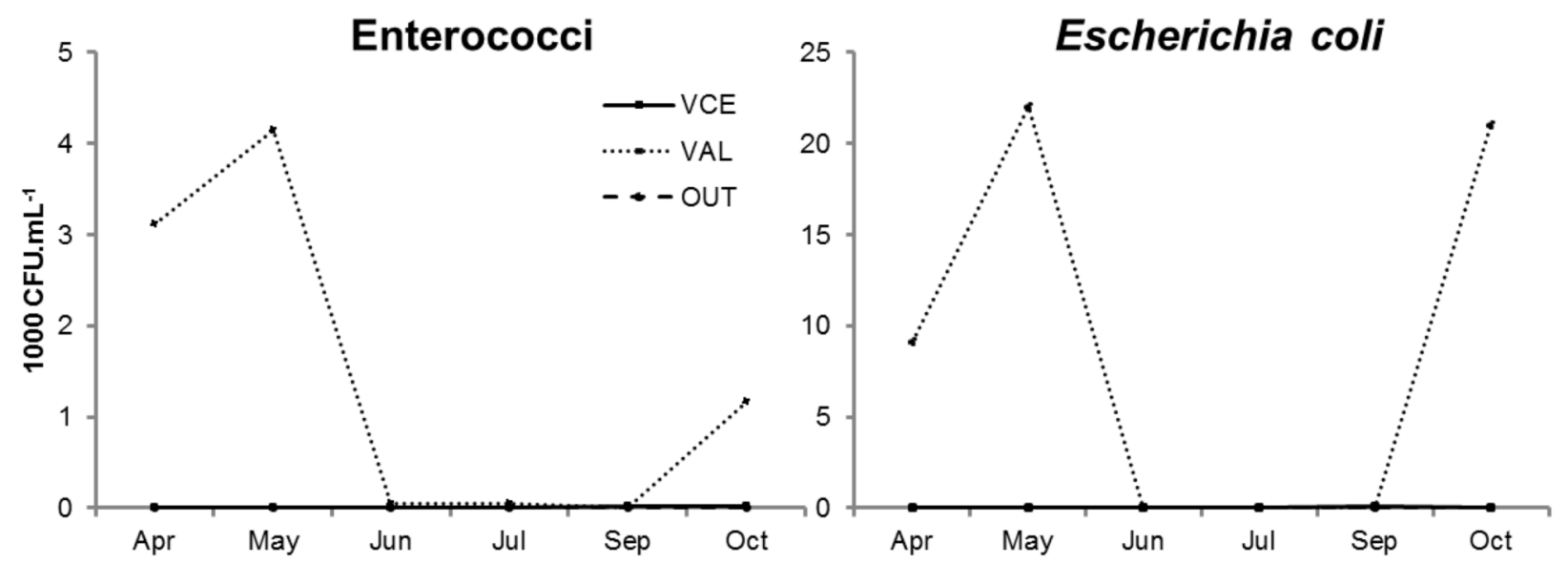

Fig. 1. Seasonality of the bacterial load at the Nesyt Pond (NAS) inlets (VAL = Valtický Brook; and VCE = Včelínek Canal) and outlet (OUT); CFU = colony forming unit
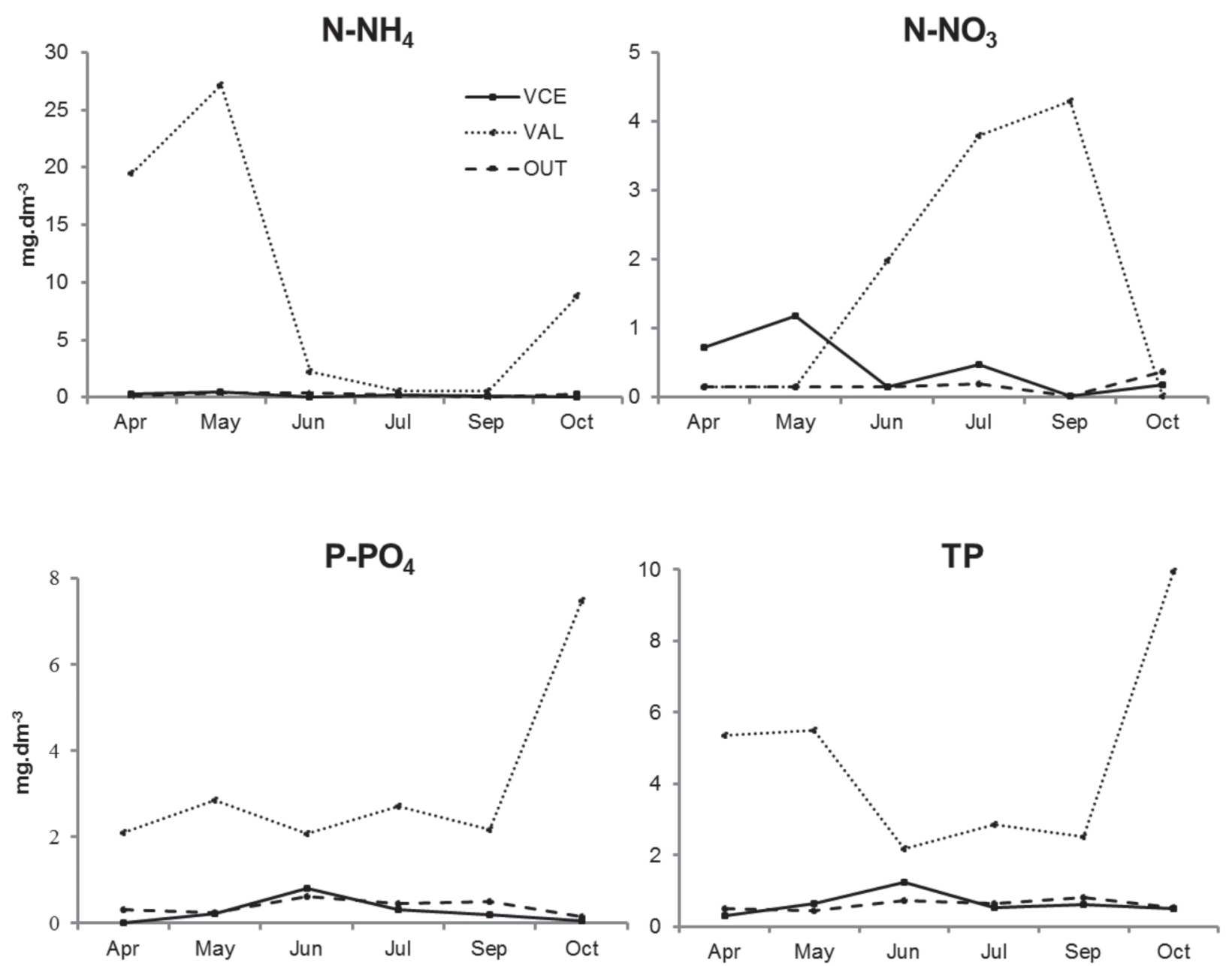

Fig. 2. Seasonality of the nutrient loading at the Nesyt Pond (NAS) inlets (VAL = Valtický Brook; and VCE = Včelínek Canal) and outlet (OUT); TP = total phosphorus 
most pronounced in October when it was reduced by 99.2 percentage points (from $605.4 \mathrm{mg} \cdot \mathrm{L}^{-1}$ to $5.0 \mathrm{mg} \cdot \mathrm{L}^{-1}$ ) at the SIB pond and by 94.9 percentage points (from $97.5 \mathrm{mg} \cdot \mathrm{L}^{-1}$ to $\left.5.0 \mathrm{mg} \cdot \mathrm{L}^{-1}\right)$ at VRK.

The decrease in nutrient concentrations was observable for all monitored forms of $\mathrm{N}$ and $\mathrm{P}$, namely $\mathrm{P}-\mathrm{PO}_{4}$, TP, N-NH $4, \mathrm{~N}_{4} \mathrm{NO}_{3}$, and TN. Our results confirm, therefore, that ponds have significant self-cleaning abilities (see Davies et al. 2001). According to Nhan et al. (2008a), concentrations of $\mathrm{N}$ and $\mathrm{P}$ were increased in water discharged from excreta-fed aquacultural ponds; however, nutrient input loading in that study was extremely high compared to the type of aquaculture practised in the Czech Republic.

Contrarily, content of TOC and SS increased at pond outlets due to increased primary production (as obvious from significant increase of chlorophyll- $a$ concentration) and, in particular, due to bioturbation activities of benthivorous carp, which are capable of deep penetration into bottom sediments during feeding (Roberts et al. 1995). According to Kloskowski (2011), bioturbation effects were more pronounced in ponds with older carp, which expel large quantities of SS and, consequently, nutrients into the water column, thus enhancing phytoplankton production. The author considers carp-induced effects on environmental conditions as both size and density dependent. This was confirmed by our observations of stronger effects at the VRK pond, which is stocked with market-size fish and whose mean individual size was the highest of all the ponds (Table 2). Bioturbation processes also caused an obvious increase in $\mathrm{BOD}_{5}$ and $\mathrm{COD}_{\mathrm{Mn}}$ values at pond outlets. The only exception was the NES pond, which showed a decline in $\mathrm{SS}$ concentration, $\mathrm{BOD}_{5}$ and $\mathrm{COD}_{\mathrm{Mn}}$ values. Here, low fish stocking density and levels of production (Rozkošný et al. 2011) due to management restrictions (mainly limited carp stocking) imposed by the NES Nature Reserve have resulted in lower bioturbation disturbance by carp which, in turn, has lead to considerably lowered resuspension of sediments into discharged water. Increased COD discharge and total suspended solids were also documented by Nhan et al. (2008a) in highly loaded excreta-fed aquacultural ponds, where they estimated that about $9 \%$ of input-N was recovered in harvested fish while $52 \%$ was accumulated in pond sediments. When considering our data on nutrient and COD discharge, however, one must keep in mind that they describe the circumstances valid for the growing season only, when food supply and bioturbation due to feeding activities of benthivorous fish are the major source of discharged SS and nutrients. As mentioned by Schreckenbach et al. (2000), the amount of organic matter present in the water column (and thus in discharged water) will be highest at the time of pond harvest.

DO concentrations and oxygen saturation values were significantly higher at the KUR, SIB, and NES pond outlets; whereas values at the VRK outlet were lower compared to its inlet water. Though the inlets of VRK provide good quality water (partly of river origin), substantial amounts of water are extracted from the pond for irrigation purposes, resulting in approximately $90 \%$ of inflow water exiting the pond prior to reaching the pond outlet (Rozkošný et al. 2011). This fully corresponds with Nhan et al. (2008a), who concluded that pond DO concentration, water exchange and nutrient discharges interacted and were strongly affected by input levels.

The SIB pond ecosystem has also been studied by Heteša et al. (2002), who compared the response of the SIB and the nearby Úvalský pond ecosystems to heavy municipal pollution. Whilst high nutrient loading resulted in well-developed phytoplankton that suppressed development of macrophytes in the SIB pond, submersed macrophytes were the dominant producers in the Úvalský pond, which totally prevented the development of small planktonic algae. According to the authors, however, both ponds exerted satisfactory self-purification effects. They estimated the TP, $\mathrm{NO}_{3}-\mathrm{N}$ and $\mathrm{NH}_{4}-\mathrm{N}$ removal rates as 57 , 47 , and 34 percentage points, respectively. The corresponding values calculated for the SIB pond (our study) were 37,52 , and 68 percentage points, respectively.

The extraordinarily high self-purification capacity of
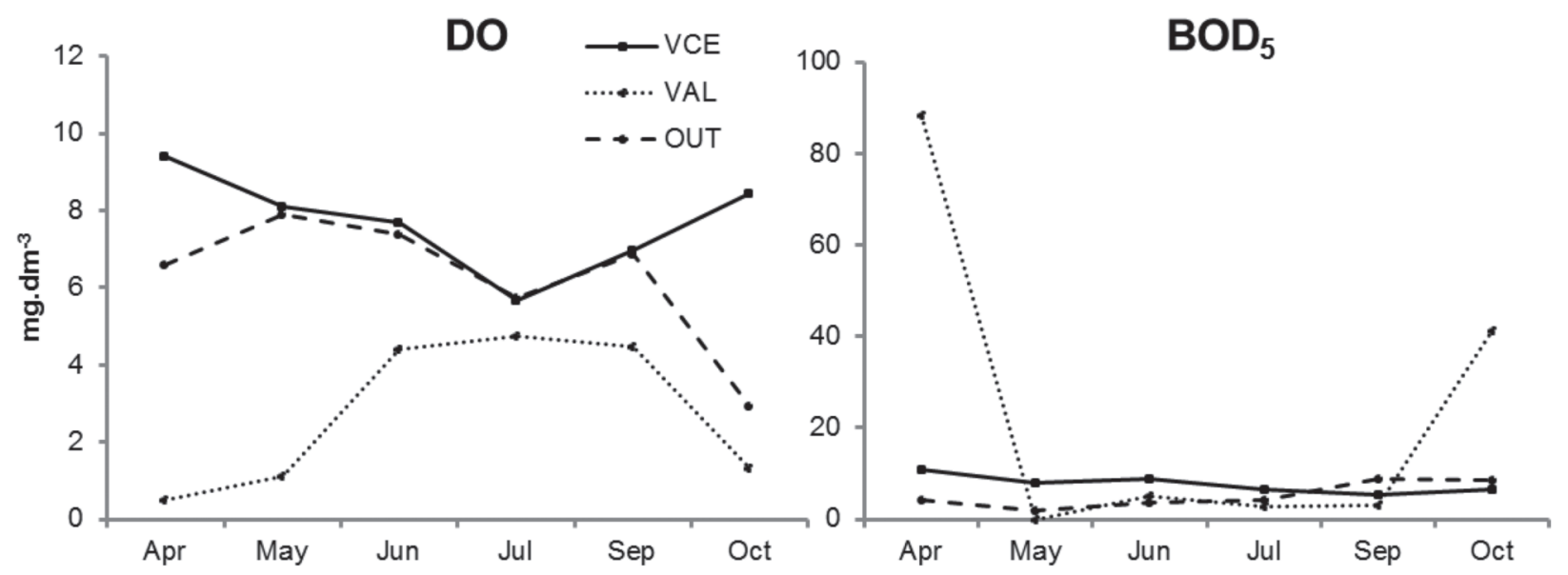

Fig. 3. Seasonality of the oxygen regime at the Nesyt Pond (NAS) inlets (VAL = Valtický Brook; and VCE $=$ Včelínek Canal) and outlet $(\mathrm{OUT}) ; \mathrm{DO}=$ dissolved oxygen, $\mathrm{BOD}_{5}=$ biochemical oxygen demand 
pond ecosystems has been documented by Mlejnková and Horáková (2009), who showed that approximately three months after semi-liquid manure application, the level of faecal and organic indicators in treated ponds did not significantly increase and did not significantly differ from non-manured ponds. In a pond supplied with municipal waste water, they demonstrated a highly significant decrease in average numbers of faecal indicators (E. coli) at the pond outflow. This is in accordance with our own observations. The presently reported our own observations yielded similar conclusions. Similar results were also reported by Kuczyński et al. (2003), who registered a thousand-fold reduction in bacteria numbers and coliform titre values in waters discharged from ponds supplied with biologically pre-treated municipal sewage. Comparative assays conducted in ponds, supplied with river water, provided values identical with those observed in the ponds supplied with sewage. Baumstark-Khan et al. (2003) and Niemi and Niemi (1991) both found that highest nutrient and bacterial pollution levels were found in samples from drainage canals collecting runoff water from fields, and not from the receiving ponds. Indeed, according to Petersen et al. (2002), integrated fish farming seems to favour antimicrobial-resistant bacteria.

In recent years, pond manuring has been strictly limited by law in the Czech Republic and is now almost never used due to the high trophic levels (occasionally to hypertrophy) reached. The main variables in Czech pond water quality, therefore, are related to food input and hydraulic retention rate, a situation identical to that noted by Nhan et al. (2006) for ponds of the Mekong delta in Vietnam. Nhan et al. (2008b) found that only $5 \%-6 \%$ of TN, TOC or P introduced into ponds was recovered in harvested fish, around 29, 81, and $51 \%$, respectively, being accumulated in sediments.

The results of our monitoring have shown that properly managed Czech carp ponds are relatively safe for the environment during the fish growing season, being not only fish producing facilities but serving also as important elements in the nutrient cycle, acting as sources and sinks for nutrients and as effective natural biofilters and digestors of various organic wastes. Nevertheless, it must be kept in mind that subsequent pond harvesting can represent a potential risk regarding discharge of considerably increased amounts of $\mathrm{SS}$ and nutrients (P in particular) into the receiving waters. Future research, therefore, should focus on these issues with the aim of elucidating the role of the various farming and harvesting techniques and of the measures available for reducing the impact of increased nutrient loads from sediment discharges during harvesting operations.

\section{ACKNOWLEDGEMENTS}

This study was supported by Grant No. CENAKVA CZ.1.05/2.1.00/01.0024 of the South Bohemian Research Centre of Aquaculture and Biodiversity of Hydrocenoses, and projects GA JU 047/2010/Z of the University of South Bohemia, QH82117 of the Czech Ministry of Agriculture, and VaV SP/2e7/73/08 of the Czech Ministry of Environment.

\section{REFERENCES}

Adamek Z., Berka R., Huda J. 2008. Carp as a traditional food fish from pond aquaculture of the Czech Republic. World Aquaculture 39 (4): 52-54/68.

Adámek Z., Helešic J., Maršálek B., Rulík M. 2010. Aplikovaná hydrobiologie. [Applied Hydrobiology.] FROV JU, Vodnany. [In Czech.]

Alabaster J.S. 1982. A survey of fish farm effluents in some EIFAC countries. Pp. 5-20. In: Alabaster J.S. (ed.) Report on the EIFAC workshop on fish farm effluents. EIFAC Technical Paper No. 41. FAO, Rome.

Baumstark-Khan C., Khan R.A., Rettberg P., Horneck G. 2003. Bacterial Lux-Fluoro test for biological assessment of pollutants in water samples from urban and rural origin. Analytica Chimica Acta 487 (1): 51-60.

DOI: $10.1016 / \mathrm{S} 0003-2670(03) 00300-3$

Bergheim A., Åsgård T. 1996. Waste production from aquaculture. Pp. 50-80. In: Baird D.J., Beveridge M.C.M., Kelly L.A., Muir J.M. (eds.) Aquaculture and water resource management. Blackwell, Oxford, UK.

Bert T.M. 2007. Environmentally responsible aquaculture: Realities and possibilities. Pp. 479-514. In: Ecological and Genetic Implications of Aquaculture Activities. Vol. 6. Reviews: Methods and Technologies in Fish Biology and Fisheries. Springer Netherlands.

Bíró P. 1995. Management of pond ecosystems and trophic webs. Aquaculture 129 (1-4): 373-386.

DOI: 10.1016/0044-8486(94)00291-U

Ciesla M., Sliwinski J., Wojda R. 2008. Traditional carp pond farming in Poland as an example of sustainable aquaculture. P. 242. In: EIFAC Symposium on Interactions between Social, Economic and Ecological Objectives of Inland Commercial and Recreational Fisheries and Aquaculture; Antalya, Turkey.

Davies C.M., Sakadevan K., Bavor H.J. 2001. Removal of stormwater-associated nutrients and bacteria in constructed wetland and water pollution control pond systems. Pp. 483-495. In: Vymazal J. (ed.) Workshop on Nutrient Cycling and Retention in Natural and Constructed Wetlands III; Trebon, Czech Republic.

Drabiński A., Jawecki B., Tokarczyk-Dorociak K. 2010. The role of carp fish ponds in the water management of the river basins. Pp. 24-29. In: Ciesla M. and Kuczynski M. (eds.) Multifunctionality in Pond Aquaculture in Poland. Perspectives and Prospects. SGGW, Warszawa, Poland.

Einen O., Holmefjord I., Åsgård T., Talbot C. 1995. Auditing nutrient discharges from fish farms: Theoretical and practical considerations. Aquaculture Research 26 (9): 701-713. DOI: 10.1111/j.1365-2109.1995.tb00960.x

Fasaic K., Debeljak L.J., Adamek Z. 1989. The effect of mineral fertilization on water chemistry of carp ponds. Acta Ichthyologica et Piscatoria 19 (1): 71-83.

Gergel J., Kratochvil A. 1984. Teiche dienen nicht nur der Fischproduktion. Zeitschrift für Binnenfischerei der DDR 31 (5): 149-154.

Heteša J., Marvan P., Kupec P. 2002. Úvalský a Šibeník - rybníky suplující funkci čistíren odpadních vod. [Úvalský and Šibeník - ponds supplying the function of wastewater treat- 
ment plant.] Pp. 239-245. In: The 5th Czech Conference of Ichthyology; MZLU, Brno. [In Czech with English summary.]

Kainz E. 1985. Zur Auswirkung von Karpfenteichabflussen auf die Wasserqualität vor Vorflutern. Österreichs Fischerei 38 (4): 88-96.

Kloskowski J. 2011. Differential effects of age-structured common carp (Cyprinus carpio) stocks on pond invertebrate communities: implications for recreational and wildlife use of carp ponds. Aquaculture International 19 (6): 1151-1164. DOI: 10.1007/s10499-011-9435-y

Knösche R.K., Schreckenbach K., Pfeifer M., Weissenbach H. 2000. Balances of phosphorus and nitrogen in carp ponds. Fisheries Management and Ecology 7 (1-2): 15-22. DOI: 10.1046/j.1365-2400.2000.00198.x

Knud-Hansen C.F., Hopkins K.D., Guttman H. 2003. A comparative analysis of the fixed-input, computer modelling, and algal bioassay approaches for identifying pond fertilization requirements for semi-intensive aquaculture. Aquaculture 228 (1-4): 189-214.

DOI: $10.1016 / \mathrm{S} 0044-8486(03) 00282-5$

Kuczyński M., Kolasa-Jamińska B., Lewkowicz S., Pilarczyk M. 2003. Production of the two-years old carp in ponds supplied with biologically pre-treated municipal sewage. Acta Scientiarum Polonorum, Seria Piscaria 2 (1): 159-168.

Markošová R., Ježek J. 1994. Indicator bacteria and limnological parameters in fish ponds. Water Research 28 (12): 2477-2485.

DOI: 10.1016/0043-1354(94)90066-3

Milstein A., Alkon A., Avnimelech Y., Kochba M., Hulata G., Schroeder G. 1991. Effects of manuring rate on ecology and fish performance in polyculture ponds. Aquaculture 96 (2): 119-138.

DOI: $10.1016 / 0044-8486(91) 90144-\mathrm{V}$

Mlejnková H., Horáková K. 2009. Vliv aplikace statkových hnojiv na fekální znečištění rybníků. [Effect of manuring upon faecal pollution of fish ponds.] Vodní hospodářství 59 (6): 11-14. [In Czech.]

Muscutt A.D., Harris G.L., Bailey S.W., Davies D.B. 1993. Buffer zones to improve water quality: a review of their potential use in UK agriculture. Agriculture Ecosystems and Environment 45 (1-2): 59-77.

DOI: 10.1016/0167-8809(93)90059-X

Nhan D.K., Milstein A., Verdegem M.C.J., Verreth J.A.V. 2006. Food inputs, water quality and nutrient accumulation in integrated pond systems: A multivariate approach. Aquaculture 261 (1): 160-173.

DOI: $10.1016 /$ j.aquaculture.2006.07.015

Nhan D.K., Verdegem M.C.J., Binh N.T., Duong L.T., Milstein A., Verreth J.A.V. 2008a. Economic and nutrient discharge tradeoffs of excreta-fed aquaculture in the Mekong
Delta, Vietnam. Agriculture Ecosystems and Environment 124 (3-4): 259-269.

DOI: $10.1016 /$ j.agee.2007.10.005

Nhan D.K., Verdegem M.C.J., Milstein A., Verreth J.A.V. 2008b. Water and nutrient budgets of ponds in integrated agriculture-aquaculture systems in the Mekong Delta, Vietnam. Aquaculture Research 39 (11): 1216-1228.

DOI: $10.1111 / \mathrm{j} .1365-2109.2008 .01986 . x$

Niemi R.M., Niemi J.S. 1991. Bacterial pollution of waters in pristine and agricultural lands. Journal of Environmental Quality 20 (3): 620-627.

Oláh J., Szabó P., Esteky A.A., Nezami S.A. 1994. Nitrogen processing and retention in Hungarian carp farm. Journal of Applied Ichthyology 10 (4): 335-340.

DOI: $10.1111 / j .1439-0426.1994 . t b 00174 . x$

Pechar L. 2000. Impacts of long-term changes in fishery management on the trophic level water quality in Czech fish ponds. Fisheries Management and Ecology 7 (1-2): 23-31. DOI: 10.1046/j.1365-2400.2000.00193.x

Petersen A., Andersen J.S., Kaewmak T., Somsiri T., Dalsgaard A. 2002. Impact of integrated fish farming on antimicrobial resistance in a pond environment. Applied and Environmental Microbiology 68 (12): 6036-6042. DOI: 10.1128/AEM.68.12.6036-6042.2002

Roberts J., Chick A., Oswald L., Thompson R. 1995. Effect of carp, Cyprinus carpio L., an exotic benthivorous fish, on aquatic plants and water quality in experimental ponds. Marine and Freshwater Research 46 (8): 1171-1180. DOI: 10.1071/MF9951171

Rozkošný M., Adámek Z., Heteša J., Všetičková L., Marvan P., Sedláček P. 2011. Vliv rybníků na vodní ekosystémy recipientů jižní Moravy. [Impact of pond management on the water ecosystems of streams in the South Moravia region.] Vodní hospodářství VTEI 61 (2): 18-21. [In Czech.]

Schreckenbach K., Knösche R., Ritterbusch D., Schöppe P., Thürmer C., Pfeifer M., Weißenbach H., Janurik E., Szabo P. 2000. Ordnungsgemäße Teichwirtschaft Auswirkungen guter fachlicher Praxis auf die Nährstoffe in Karpfenteichen und Vorflutern. Schriften des Instituts für Binnenfischerei e.V. Potsdam-Sacrow 8: 30-33.

Všetičková L., Adámek Z. 2012. The impact of carp pond management upon macrozoobenthos assemblages in recipient pond canals. Aquaculture International.

DOI: $10.1007 / \mathrm{s} 10499-012-9565-\mathrm{x}$

Received: 13 April 2012

Accepted: 17 August 2012

Published electronically: 30 September 2012 